\title{
7o-Yazarın zihninde bir çeviri edimi: Özde çeviri ürünü olarak kaynak metin ve aslına çevirisi ${ }^{1}$
}

\section{Didem TUNA²}

\begin{abstract}
APA: Tuna, D. (2020). Yazarın zihninde bir çeviri edimi: Özde çeviri ürünü olarak kaynak metin ve aslına çevirisi. RumeliDE Dil ve Edebiyat Araştırmaları Dergisi, (Ö8), 882-904. DOI: 10.29000/rumelide.814738.
\end{abstract}

\section{$\ddot{O} \mathbf{z}$}

Çevirmen, belli bir edebiyat türüne ait olan ya da ilgi ve uzmanlık alanı dışında kalan konularda yazılan metinleri çevirmeyi mesleki ya da kişisel açıdan tercih etmeyebilir. Örneğin, dize formatında yazılmış oyunların çevirisi, türe ilgi duymayan ya da kendini bu türden bir aktarım için yetkin ya da hazır hissetmeyen bir çevirmen için cazip bir seçenek olmayabilir. Çevirmen aynı şekilde din, felsefe ya da tarih alanlarında, sanatın belirli dallarında, özel alan ya da terim bilgisi gerektiren konularda yazılmış metinlerin çevirisine tereddütle yaklaşabilir. Diğer yandan, çevirmenin bir nedenle çevirisini üstlenmeye sıcak bakmayabileceği bazı konular, sıcak baktığı farklı bir metnin içinde çözümlenmesi gereken metinlerarası unsurlar olarak karşısına çıkabilir. Bu unsurlar kimi zaman ciddi araştırma gerektiren, çeviriye ve çevirmene birçok açıdan meydan okuyan, tam anlaşılmayan ya da anlaşılsa dahi aktarılmaya direnen özellikte olabilir. Bu çalışmada Alexandre Dumas'nın Ali Pacha adlı kitabı, Sündüz Öztürk Kasar’ın önerdiği özde çeviri kavramı üzerinden diller ve kültürlerarası zihinsel bir çeviri ürünü olarak incelenmekte, İngilizce çevirisi ile tarafımızca yapılan Türkçe çevirisi ise Öztürk Kasar'ın yine aynı kavramdan yola çıkılarak tanımlanmış olduğu dolaylı özde çeviri ve aslına çeviri kavramları üzerinden ele alınmaktadır. Bu yaklaşımla, özünde (Türkçeden) çeviri işlemi olan (Fransızca) bir özgün metnin üçüncü bir dile (İngilizceye) aktarılması ve aslına (Türkçeye) döndürülmesi sırasında çevirmenin karşısına çıkabilecek farklı alanlara ait göstergelere dair örneklere yer verilmekte, bu örnekler üzerinden çevirinin metinlerarası ve disiplinlerarası doğası vurgulanarak, çevirmenin neyi çevirip neyi çevirmeyeceği üzerinde ne kadar kontrolü olabileceği irdelenmektedir. Bunun yanı sıra, bir özde çeviri metnini dolaylı özde çeviri ve aslına çeviri metnine döndürme noktasında çevirmenleri bekleyen farklı yükümlülüklere değinilmektedir.

Anahtar kelimeler: Ali Pacha, özde çeviri, dolaylı özde çeviri, aslına çeviri, çeviride metinlerarasılık

\section{An act of translation in the author's mind: The source text as a product of watermark translation and its retro-translation}

\begin{abstract}
Translators may professionally or personally choose not to translate texts belonging to a specific literary genre or those that are outside of their area of interest and expertise. For example, the translation of plays written in verse form may not be an attractive option for translators who are not

Bu calıșmanın bir bölümü Trakya Üniversiteler Birliği tarafından Bandırma Onyedi Eylül Üniversitesince 2-5 Eylül tarihleri arasında düzenlenen Uluslararası Filoloji Çalışmaları Konferansında "Karma Nitelikli Metin Karşısında Çevirmenin Tutumu" başlı̆̆ıly sunulmuştur.

Doç. Dr., İstanbul Yeni Yüzyll Üniversitesi, Fen Edebiyat Fakültesi, İngilizce Mütercim Tercümanlık Bölümü (İstanbul, Türkiye), didem.tuna@yeniyuzyil.edu.tr, ORCID ID: 0000-0002-1566-9503 [Makale kayıt tarihi: 17.09.2020-kabul tarihi: 20.11.2020; DOI: 10.29000/rumelide.814738]
\end{abstract}


interested in the genre or do not feel competent or ready to work in that area. In the same way, they may be reluctant to translate texts belonging to the fields of religion, philosophy, or history, to certain branches of art or in topics that require specialized knowledge. On the other hand, some topics which the translator may not want to undertake in translation for some reason may appear in another text to be translated as intertextual elements needing to be analyzed. These issues may sometimes necessitate serious research and challenge translation and translators in many respects. Sometimes, these subjects are not fully understood or may resist translation. In this study, Ali Pacha by Alexandre Dumas is examined through Sündüz Öztürk Kasar's concept of watermark translation as an interlingual and intercultural act accomplished in the author's mind, and its English and Turkish translations are treated within the framework of indirect watermark translation and retro-translation. Through this approach, a variety of signs from different fields that a translator may have to deal with are provided, within the scope of the transmission of a (French) source text as watermark translation (into English and Turkish). With these examples, the intertextual and interdisciplinary nature of translation is emphasized, with a focus on how much control translators can have on their choices as to what to translate or not. In addition, different responsibilities translators may be faced with in indirect watermark translation and retrotranslation are discussed.

Keywords: Ali Pacha, watermark translation, indirect watermark translation, retro-translation, intertextuality in translation

\section{Giriş}

Engel tanımazlığı, hırsı ve acımasızlığı ile nam salan Tepedelenli Ali Paşa, Yanya’nın kuzeybatısında yer alan Tepedelen'de 1740 ya da 1744'te dünyaya gelmiş olup, hüküm sürdüğü dönemde çok geniş bir bölgeyi yönetimi altına almayı başarmış önemli bir mahalli idarecidir. Kökenine ilişkin farklı bilgiler olmakla birlikte, paşalık beratında adı Anadolulu Ali olarak geçmekte olup, büyükbabası Muhtar Bey ile babası Veli Paşa Tepedelen mütesellimi olarak görev yapmışlardır. Ali’nin gençliği babasını kaybettikten sonra akrabalarıyla mücadele içinde geçer; önce derbentler başbuğu Kurt Ahmed Paşa'nın ve sonra da Delvine mutasarrıfı Kaplan Paşa'nın himayesine girer. Kaplan Paşa'nın kızı ile evlenmesine rağmen onun idamında rol oynar. Delvine mutasarrıfı Mustafa Paşa katledilince onun yerine getirilerek, Delvine ile beraber sonradan iptal edilmekle birlikte Yanya'ya mutasarrif olur. Sonrasında Tırhala mutasarrıflığı ve Tesalya ile Epir bölgesindeki dă̆ geçitlerinin güvenliğinden sorumlu derbentler başbuğluğuna getirilir. 1787'de Yanya sancağını elde ederek otuz üç yıl idaresinde kalacak olan bu sancakta konumunu sağlamlaştırıp derbentler paşalığına yükselir. Oğulları Muhtar ve Veli'nin elde ettikleri makamlarla artan nüfuzu ve gücü gittikçe pekişir. II. Mahmut'un merkezi otoriteyi sağlama politikası, adeta bağımsız bir tutum içinde her geçen gün etki alanını genişleten Ali Paşa'nın ortadan kaldırılmasını kaçınılmaz kılar. Kendi derbentler başbuğluğundan, oğlu Veli de Tırhala paşalığından azledilirken, çeşitli yerlerdeki askerlerini geri çekmek kaydıyla Yanya uhdesinde bırakılır. Kendi idaresinde bir Rum eyaleti kurmaya girişmesi üzerine vezirliği kaldırılır, Yanya valiliğinden azledilerek Tepedelen'de zorunlu ikamete mahkum edilir; bunu reddetmesi üzerine de fermanlı olarak cezaya çarptırılır. Yanya'da iki yıl kadar devam eden direniş sürecinde Rum isyanı yayılır. İdamına dair düzmece olarak tertip edilen bir ferman uygulanmak istendiğinde silâhla karşıllı verince çıkan çatışmada 1822 yılında öldürülür. İstanbul'a getirilen başı, üzerine suçlarını ifade eden bir yafta iliştirilmiş olarak teşhir edilir. Modern Arnavut tarihçileri tarafından bağımsız bir Arnavutluk kurulmasının öncüsü olarak düşünülen Ali Paşa, Avrupa'da "Yanya aslanı" sıfatıyla tanınmış, 
An act of translation in the author's mind: The source text as a product of watermark translation and its retro-translation / D. Tuna (pp. 882-904)

efsanelere konu olmuş ve hakkında birçok yapıt kaleme alınmıştır.3 Bu yapıtlardan biri de, Alexandre Dumas'nın bu çalışmamızın bütüncesinde yer alan Ali Pacha başlıklı kitabıdır (Dumas, 1840). Bu kitabın yine Ali Pacha adlı İngilizce çevirisi (Dumas, 2011)4 ile tarafımızca yapılan Tepedelenli Ali Paşa başlıklı Türkçe çevirisi (Dumas, 2020) ise bütüncemizi oluşturan diğer iki kitaptır.

Dumas'nın Félicien Mallefille ile birlikte kaleme aldığı Ali Pacha başlıklı yapıtı, Crimes célèbres (Ünlü Suçlar) adlı tarih serisinin bir parçasıdır. Bu seri, ünlü suçluları ya da mağdurları konu alan on sekiz kitaptan oluşmaktadır. Kitaplarda ele alınan dönemler Rönesans'tan Dumas'nın yaşadığı döneme kadar uzanmakta olup, Dumas bu seri için muazzam bir araştırma yürütmüştür.5 Öncelikli olarak bir roman ve bir tarih kitabı olarak okunabilen Ali Pacha, metinlerarası ilişkilerle örülmüştür. Bu nedenle, çevirmen açısından da ciddi bir araştırma süreci gerektiren özel bir metindir.

Julia Kristeva, "her kelimenin (ve metnin) diğer kelimelerin (ve metinlerin) bir kesişim noktası olduğunu ve her kelimede (ve metinde) başka bir kelimenin (ve metnin) okunabildiğini” (1980: 66) öne sürmüştür. Kristeva'ya göre, "her metin alıntılar mozaiği olarak oluşturulur; her metin başka bir metnin dönüştürümüdür” (Kristeva, 1986: 37). Ali Pacha başlıklı romanı bu tanımlamaların ışığında düşündüğümüzde tarih, askerlik, din, coğrafya ve sosyoloji başta olmak üzere bir çok farklı alandan çeşitli alıntılarla kendi mozaiğini oluşturmuş karma bir metin olduğu gözlemlenebilir. Belli bir coğrafya üzerinde tarihten belli bir kesiti yansıtan bir roman olmasının yanı sıra, aynı zamanda bir cinayet romanıdır, içinde yer yer bir aşk romanından izler bulmak isteyenler de olabilir; ancak aynı zamanda türlü türlü vahşetin yanı sıra cinsiyet ayrımcılığının da başyapıtıdır. Feodal bir yapının tüm insanlara yönelttiği zulmü ve içindeki ataerkil düzenin de kadınlara dayattığı her çeşit fiziksel, cinsel, psikolojik ve ekonomik şiddeti son derece ağır örneklerle yansıtmaktadır.

Kitapta yer alan kişi adları, yer adları ve diğer özel adlar ile dinsel, kültürel ya da dönemsel öğeler gerçek olmakla birlikte, Fransızca adlarıyla, yazılışlarıyla ya da algılanış şekilleriyle ifade edilmiştir. Bunların İngilizce çevirisinde genellikle aynı adlandırmalar korunmuştur. Ancak Türkçe çeviri söz konusu olduğunda, bu ifadelerin aslına döndürülmesi gereksinimi ortaya çıkmaktadır. Bu çalışmada Sündüz Öztürk Kasar’ı önerdiği özde çeviri, dolaylı özde çeviri ve aslına çeviri kavramları (2012; 2020) bu noktada devreye girmekte ve Dumas'nın özgün metni ile İngilizce ve Türkçe çevirileri bu kavramlar üzerinden ele alınmaktadır. Bu yaklaşımla, özünde (Türkçeden) çeviri işlemi olan (Fransızca) bir özgün metnin üçüncü bir dile (İngilizceye) aktarılması ve aslına (Türkçeye) döndürülmesi sırasında çevirmenin karşısına çıabilecek farklı alanlara ait göstergelere dair örneklere yer verilmekte, bu örnekler üzerinden çevirinin metinlerarası ve disiplinlerarası doğası vurgulanarak, çevirmenin neyi çevirip neyi çevirmeyeceği üzerinde ne kadar kontrolü olabileceği irdelenmektedir. Bunun yanı sıra, bir özde çeviri metnini dolaylı özde çeviri ve aslına çeviri metnine döndürme noktasında çevirmenleri bekleyen farklı yükümlülüklere değinilmektedir.

\section{2. Özde çeviri, dolaylı özde çeviri ve aslına çeviri kavramları}

Tepedelenli’nin doğumundan bir asır sonra kaleme alınan Ali Pacha'nın, Osmanlı topraklarında geçen tarihi bir roman olduğundan söz etmiştik; ancak aslında Dumas yazdığı romanın tarihine yabancıdır;

3 Türkiye Diyanet Vakfı İslam Ansiklopedisi. https://islamansiklopedisi.org.tr/tepedelenli-ali-pasa. [28.07.2020]

$4 \quad$ Gutenberg Projesi kapsamında yayınlanan ve bu çalıșmamızda kullandığımız İngilizce metinde çevirmen adı belirtilmemiştir. Metnin diğer bir yayıncısı olan Floating Press ile yaptığımız e-posta yazışmasında, kullandıkları metinde çevirmen adı belirtilmediği ancak çevirinin I.G. Burnham'ın 1895 te yaptı̆̆ çevirisi olduğunu tahmin ettikleri bilgisini vermişlerdir.

5 Alexandre Dumas, Deux Siècles de Littérature Vivante. www.dumaspere.com/pages/dictionnaire/crimes_celebres.html [01.08.2020]. 
coğrafyasına, diline, kültürüne, yaşantısına yabancıdır. Bu anlamda bu yapıtı yabancı bir bağlamdan üreterek kendi öz bağlamına kendi diliyle taşımıştır. Bu durum da bizi Öztürk Kasar'ın geliştirdiği özde çeviri $(2012 ; 2020)$ kavramına yöneltmektedir.

Öztürk Kasar'ın tanımıyla özde çeviri "yayınlanmış olduğu yerel dil bağlamında özgün eser olarak üretilmiş ancak özünde zihinsel bir çeviri işleminin yer aldığı bir ürüne işaret etmektedir" (2020: 3). Böylesi bir çeviri işleminde "yazar yapıtını oluştururken bir dilden diğerine, bir kültürden diğerine zihninde gerçekleştirdiği bir çeviri işlemi aracılı̆̆ıyla geçer ve bu zihinsel çeviri işlemi tıpkı kâğıt paraların dokusundaki filigran gibi metnin dokusunda bir iz bırakır" (2020: 3). Bu nedenle Öztürk Kasar, özde çeviriyi ilk kez Fransızca olarak tanımladığında "traduction en filigrane" (filigran çeviri) terimiyle kavramlaştırmıştır (2012). Bu yaklaşımdan yola çıkarak, Dumas'nın Fransızca olarak yazdığı özgün metnin özünde de zihinsel bir çeviri işlemi olduğunu ve bu işlemin metnin dokusuna işlediğini söyleyebiliriz. Tepedelenli'nin hikâyesini yazmak için ciddi bir araştırma yapan Dumas, elde ettiği bulguları alımlayan özne olarak yorumlayıp onlardan anlam üretmiş (Öztürk Kasar, 2009: 171), başka bir deyişle yabancı bağlamdan alımladıklarını zihninde kendi diline çevirip aktarmıştır. Öztürk Kasar, özde çeviri kavramını iki başılı altında sınıflandırmaktadır: Öz bağlamdan yabancı bağlama giden özde çeviriler ve yabancı bağlamdan öz bağlama giden özde çeviriler (2020: 4-5). Dumas'nın metni özelliği gereği yabancı bağlamdan öz bağlama giden bir özde çeviri kapsamındadır.

Öztürk Kasar, yabancı bağlamdan öz bağlama giden özde çevirilerin çıkış noktasında yazarın yabancı diyara duyduğu hayranlık gibi olumlu güdülenmelerin yanı sıra kınama, hor görme gibi olumsuz tepkilerin de yer alabileceğinden ve bazen de tarafsız bir yaklaşımın söz konusu olabileceğinden söz etmektedir. Öztürk Kasar’a göre yansıtılan yabancı bağlamın çok iyi tanınmasını gerektiren bu tür bir üretimde her şeye karşın kimi algılama farklılıkları da mevcut olabilmekte ve bu farklılıklar metinde iz bırakabilmektedir (2020: 5). Bu noktada, Dumas'nın da yabancı bir diyara ait bir tarihi ve hikâyeyi, kendi algısı doğrultusunda kendi diline doğru bir zihinsel çeviri işleminden geçirmiş olduğu ve ortaya koyduğu özde çeviri niteliğindeki kaynak metnin de vardı̆̆ı yargıların bir çıtısı olduğu söylenebilir. Nitekim, Gutenberg Projesi kapsamında yayınlanan ve içinde kitabın İngilizce çevirisinin de yer aldı̆̆ Celebrated Crimes e-kitabının başına düşülen notta, seride yer alan kitaplarda gerçeklerin yer yer saptırılmış göründüğünden ve yazarın kimi zaman mesnetsiz suçlamalarda bulunduğundan söz edilmekte ancak Dumas'nın yazdıklarının tarihsel yönünü düzeltmenin kendilerine düşmeyeceğinden bahisle, kitapları erek kitlesi olan dikkatli ve olgun okurun bunları fark edip göz önünde bulunduracağı ifade edilmektedir. Aynı kaynağın giriş bölümde ise Ali Paşa'nın akıl almaz zulmünün yalnızca Dumas'ya mal edilmemesi gerektiği, zira Dumas'nın bu yapıt konusunda gölge yazarlarından biri olan Mallefille'den epeyce yardım aldığına değinilmektedir. ${ }^{6}$ Bu noktada, zihinde gerçekleştirilen özde çeviri işlemine metnin gölge yazarının da dahil olduğu söylenebilir.

Kaynak metnin özde çeviri olarak tanımlandığı durumlar, akla bu metinlerin çevirisinin nasıl adlandırabileceği sorusunu getirmektedir. Öztürk Kasar bu kapsamdaki bir çeviriyi Fransızca olarak tarif ederken "quasi traduction de seconde langue" (2012: 267) (neredeyse ikinci dilden çeviri) ifadesini kullanmış, daha sonra da bu ifadeyi “dolaylı özde çeviri” (2020: 7) olarak güncelleyip terimleştirmiştir. Öztürk Kasar, dolaylı özde çeviri terimini öz bağlam dilinden farklı bir üçüncü dile yapılan çevirilerden söz etmek için kullanmakta olup, özde çeviriyi öz bağlamına döndüren çeviriler için ise "aslına çeviri" terimini öne sürmüştür. Bu anlamda, bütüncemizde yer alan Fransızca kaynak metin özde çeviri kavramına, İngilizce çevirisi dolaylı özde çeviri kavramına ve Türkçe çevirisi ise

Dumas, A. Celebrated Crimes, Complete. https://www.gutenberg.org/files/2760/2760-h/2760-h.htm [03.08.2020]. 
An act of translation in the author's mind: The source text as a product of watermark translation and its retro-translation / D. Tuna (pp. 882-904)

aslına çeviri kavramına birer örnek oluşturmaktadır. Bu noktada, kimi metinler özelinde aslına çeviri işleminin dolaylı özde çeviri işleminden farklı bir çaba gerektirdiği söylenebilir. Dolaylı özde çeviri söz konusu olduğunda, özde çeviri metni üzerinden hareket etmek yeterli olabilirken, metni aslına döndürmek için gereken göstergelerin araştırılması ek çalışmalar yapmayı zorunlu kılmaktadır.

\section{3. Özde çeviri, dolaylı özde çeviri ve aslına çeviri bağlamında özel adların aktarılması}

Çalışmanın bu bölümünde özel ad çevirisi başlı̆̆ altında kişi adları; halk, toplum ve topluluk adları; coğrafi oluşum ve yer adları incelenmektedir.

\subsection{Kişi adlarının aktarılması}

Ali Paşa'nın hikâyesinde gerek önemli tarihi şahsiyetler gerekse onların hayatlarının merkezinde var olmuş birçok tanınan ya da tanınmayan sima mevcuttur. Bu simalar, Osmanlı İmparatorluğu'nun farklı coğrafyalarında yaşayan, farklı etnik kökenlere ve dinlere mensup karakterler olarak romanda yerlerini almışlardır. Bu çalışma kapsamında özde çeviri metni olarak ele aldığımız özgün metinde de Türkçe, Rumca ve Arnavutça başta olmak üzere çeşitli dillerden kişi adları ve bazen de lakapları yer almaktadır.

Tablo 1. Kişi adları ${ }^{7}$

\begin{tabular}{|l|l|l|}
\hline $\begin{array}{l}\text { Fransizca Kaynak Metin } \\
\text { Özde Çeviri }\end{array}$ & $\begin{array}{l}\text { İnilizce Erek Metin } \\
\text { Dolaylı Özde Çeviri }\end{array}$ & $\begin{array}{l}\text { Türkçe Erek Metin } \\
\text { Aslına Çeviri }\end{array}$ \\
\hline Djezzar-pacha & Djezzar Pacha & Cezzar Paşa \\
\hline Passevend-Oglou-pacha & Passevend-Oglou Pacha & Pasvantoğlu Paşa \\
\hline Sultan-Sélim & Sultan Selim & Sultan Selim \\
\hline Czerni-Georges & Czerni-Georges & Kara Yorgi \\
\hline Méhémet-Ali & Mahomet Ali & Kavalalı Mehmet Ali Paşa \\
\hline Ali-Tébélen & Tepeleni & Tepedelenli Ali Paşa \\
\hline Ortogrul & Ortogrul & Ertuğrul \\
\hline Scander-Beg & Scander Beg & İskender Bey \\
\hline Bayezid-Ildérim & Bajazet Ilderim & Ylldırım Bayezit \\
\hline Mouktar Tébélen & Mouktar Tepeleni & Tepedelenli Muhtar \\
\hline Salick & Salik & Salih \\
\hline Véli & Veli & Veli \\
\hline Kamco & Kamco & Hanko \\
\hline Kourd-pacha & Kourd Pacha & Kurt Paşa \\
\hline Chaïnitza & Chainitza & Şehnisa \\
\hline Capelan-le-Tigre & Capelan Tigre & Kaplan Paşa \\
\hline Emineh & Emineh & Emine \\
\hline Soliman & Soliman & Süleyman \\
\hline Moustapha & Mustapha & Mustafa \\
\hline Mahmoud & Mahmoud & Mahmut \\
\hline & &
\end{tabular}

7 Bu çalışmadaki tablolarda yer alan unsurlar, kitapta yer alma sırasına göre dizilmiştir. 


\begin{tabular}{|c|c|c|}
\hline Sépher Bey & Sepher Bey & Sefer Bey \\
\hline Zadé & Zaidee & Zaide \\
\hline Mourad & Murad & Murat \\
\hline Euphrosyne & Euphrosyne & Efrozin \\
\hline Elmas-bey & Elmas Bey & Elmas Bey \\
\hline Vasiliki & Basilessa & Vasiliki \\
\hline Nouza & Nouza & Nuza \\
\hline Aden-bey & Aden Bey & Adem Bey \\
\hline Ismaël Pacho-bey & Ismail Pacho Bey & İsmail Paşo Bey \\
\hline Athanase Vaya & Athanasius Vaya & Tanaş Vaya \\
\hline Cheïk Jousouf & Sheik Yussuf & Şeyh Yusuf \\
\hline Moustaï & Moustai & Mustay \\
\hline Zobéide & Zobeide & Zübeyde \\
\hline Jousouf & Yussuf Bey & Yusuf Bey \\
\hline Saint-Bazile & St. Basil & Aziz Vasilios \\
\hline Aïsché & Ayesha & Ayşe \\
\hline Athanase Macrys & Athanasius Macrys & Tanaş Makris \\
\hline Vierge de Parga & Virgin of Parga & Parga'nın Bakire Meryem’i \\
\hline Xénoclès & Xenocles & Ksenokles \\
\hline Paléopoulo & Paleopoulo & Paleopulo \\
\hline Abdi-Effendi & Abdi Effendi & Abdi Efendi \\
\hline Khalet-Effendi & Khalid Effendi & Halet Efendi \\
\hline Suleyman-pacha & Suleyman Pacha & Süleyman Paşa \\
\hline Anagnoste & Anagnorto & Anagnos \\
\hline Abas & Abbas & Abbas \\
\hline Porphyre & Porphyro & Porfiri \\
\hline Omer Brionès & Omar Brionis & Ömer Viriyoni \\
\hline Krim-Guérai & Krim Guerai & Kırım Giray \\
\hline Hassan-Stambol & Hassan-Stamboul & İstanbullu Hasan \\
\hline Kékriman & Kekriman & Kekriman \\
\hline Hussein-pacha & Hussien Pacha & Hüseyin Paşa \\
\hline Marc Botzaris & Morco Botzaris & Mark Boçaris \\
\hline Kourchid-pacha & Kursheed Pacha & Hurşit Paşa \\
\hline Alexis Noutza & Alexis Noutza & Aleksis Nuça \\
\hline İbrahim Aga Stambol & Ibrahim-Aga Stamboul & İstanbullu İbrahim Ağa \\
\hline Baltadg-pacha & Baltadgi Pacha & Baltacı Paşa \\
\hline Kyr Lekos & Kyr Lekos & Kir Lekos \\
\hline Bim Bachi Aslon & Bimbashi Aslon & Binbaşı Aslan \\
\hline Alexandre Hypsilantis & Alexander Ypsilanti & Aleksandros İpsilantis \\
\hline
\end{tabular}


An act of translation in the author's mind: The source text as a product of watermark translation and its retro-translation / D. Tuna (pp. 882-904)

\begin{tabular}{|l|l|l|}
\hline Metzo-Abbas & Metzo-Abas & Meço Abbas \\
\hline Dgé-ladin & Djiladin Pacha & Celaleddin \\
\hline Tahir Abas & Tahir Abbas & Tahir Abbas \\
\hline Hagi Bessiaris & Hagi Bessiaris & Hacı Vasyari \\
\hline Nekibé & Nekibi & Nekibe \\
\hline Sélim & Selim & Selim \\
\hline Ismaël-Pliaga & Ismail Pliaga & İsmail Pliaga \\
\hline Othman & Othman & Osman Gazi \\
\hline Katherin & Katherin & Katerin \\
\hline Metché-Bono & Metche-Bono & Maço Bono \\
\hline
\end{tabular}

Tablo 1'de görüldüğü gibi yazar, kitapta geçen bu adları, lakapları ve adlarla birlikte yer alan unvanları Fransızca metne transkripsiyonla aktarmış ve böylelikle az çok telaffuz edildikleri şekilde ifade etmiştir. Bu kapsamdaki Türkçe, Arapça ya da Farsça kökenli olan ve anlatı zamanında olduğu gibi günümüzde de kullanılan Türk adlarını Türkçe erek metin yoluyla aslına döndürmek genel anlamda bir sorun arz etmezken, diğer dillerdeki isimlerin Osmanlı bağlamında nasıl ifade edildiğini saptamak için araştırma yapmak gerekmiştir. Czerni Georges, Euphrosyne, Athanase Macrys, Hagi Bessiaris gibi Sırpça, Rumca ve Arnavutça kökenli isimler bunlara örnektir. Diğer yandan, dolaylı özde çeviri kapsamında ele aldığımız İngilizce erek metinde bu türden bir kaygı söz konusu olmayıp, kişi adları ya Fransızca kaynak metinde olduğu gibi aktarılmış, ya da transkripsiyonun İngilizce okunuşa uygun olarak düzenlenmesiyle yetinilmiştir.

\subsection{Halk, toplum ve topluluk adlarının aktarılması}

Tepedelenli Ali Paşa'nın hikâyesinin geçtiği Osmanlı toprakları bugün sınırları yeniden çizilmiş bir coğrafyadır. Kitapta adı geçen halk, toplum ve topluluk adlarının birçoğu günümüzde geçerli değildir. Bu durum, bu adların aktarımını da özel olarak zorlu kılmaktadır. Sınırları farklı bir coğrafyada evvel zaman içinde yer almış bir yer adını o zamanki aslına döndürmek, ayrıntılı bir araştırmayı zorunlu kılmaktadır.

Tablo 2. Halk, toplum ve topluluk adları

\begin{tabular}{|l|l|l|}
\hline $\begin{array}{l}\text { Fransızca Kaynak Metin } \\
\text { Özde Çeviri }\end{array}$ & $\begin{array}{l}\text { İnilizce Erek Metin } \\
\text { Dolaylı Özde Çeviri }\end{array}$ & $\begin{array}{l}\text { Türkçe Erek Metin } \\
\text { Aslına Çeviri }\end{array}$ \\
\hline Osmanlis & Osmanli & Osmanlı \\
\hline Scythes & Scythians & İskitler \\
\hline Schypétars & Skipetar & İsckiptarlar \\
\hline Bektagis & Bektagis & Bektaşiler \\
\hline Iapyges & Tapygae & Laplar \\
\hline Schypetars Toxides & Skipetars of Toxid & Toskalık Arnavutları \\
\hline Souliotes & Suliots & Suliyotlar \\
\hline Valaque & Wallachian & Eflaklı \\
\hline Tatar & Tartar & Tatar \\
\hline Chrétiens Mirdites & Christian Mirdites & Mirdita Huristiyanları \\
\hline
\end{tabular}




\begin{tabular}{|l|l|l|}
\hline Paxinotes & Sailors from Paxos & Paksulular \\
\hline Bourbons & Bourbons & Bourbon hanedanı \\
\hline Hellènes & Greeks & Helenler \\
\hline Parganiotes & Parganiotes & Pargalılar \\
\hline Hydriotes & Hydriotes & İdralılar \\
\hline Armatolis & Armatous & Armatoller \\
\hline Klephtes & Klephotes & Kleftler \\
\hline Grecs & Greeks & Rumlar \\
\hline Monténégrins & Montenegrins & Karadağllar \\
\hline Guègues & Guegues & Gegalar \\
\hline Chaoniens & Chaonians & Kaonyalılar \\
\hline Kersales & Kersales & Kersallar \\
\hline Mameluks & Mamelukes & Memluklar \\
\hline
\end{tabular}

Tablo 2 incelendiğinde Osmanlılar, Bektaşiler ya da Memluklar gibi bilinen halk, toplum ve topluluk adlarının yanı sıra, günümüzde tarihle özel olarak ilgilenenlerin dışında kalanlar için yabancı olan birçok ad söz konusudur. Yazar, bu adları metne Fransızca ile uyumlu bir transkripsiyonla aktarmış ve böylelikle az çok telaffuz edildikleri şekilde ifade etmiştir. Diğer yandan, bu isimleri çoğul yapmak için de sonlarına Fransızca çoğul eki olan -s ilave etmiştir. Özde çeviriyi Osmanlis, Bektagis ya da Mameluks gibi bilinen adlar bağlamında aslına döndürmek ya da günümüzde hala Parga olarak anılan şehrin sakinlerini ifade etmede kullanılan Parganiotes sözcügünü Türkçe kurallarına ve transkripsiyonuna uygun olarak Pargalılar şeklinde aktarmak bir sorun olmasa da, Iapyges, Schypetars Toxides, Paxinotes gibi adları aslına çevirmek ciddi bir araştırma ve doğrulama gerektirmiştir. Bu çalışmalar yapılırken, çeşitli yazılı kaynaklara başvurulmasının yanı sıra, aynı zamanda dönemin haritalarına ulaşılması da zorunlu olmuştur. Diğer yandan, dolaylı özde çeviri kapsamında ele aldığımız İngilizce erek metinde bu adlar ya Fransızca kaynak metinde olduğu gibi aktarılmış, ya da transkripsiyon İngilizce okunuşa uygun olarak düzenlenmiştir. Bunların yanı sıra, yazarın armatolis ve klephtes olarak aktardı̆̆ Yunanca kökenli sözcüklerin o dönemde armatol ve kleft olarak ifade bulduğu saptanmıştır. Bu kelimelerin kökeni ve anlamına yönelik ayrıntılar için metne editör tarafından dip not düşülmüştür.

\subsection{Coğrafi oluşum ve yer adlarının aktarılması}

Çalışmanın bu bölümünde, coğrafi oluşum ve yer adları geniş bir bağlamda ele alınmaktadır. Dağ, geçit, vadi, göl, çay, nehir, deniz, burun, ada, takımada gibi coğrafi oluşumları yanı sıra, sınırlarını insanların çizdiği her tür yerleşim yeri, köy, kasaba, şehir ve ülke adı ile kale, manastır ve cami gibi insan yapımı mekân ve kurum adları da bu başlık altında incelenmektedir.

Tablo 3. Coğrafi oluşum ve yer adları

\begin{tabular}{|l|l|l|}
\hline $\begin{array}{l}\text { Fransızca Kaynak Metin } \\
\text { Özde Çeviri }\end{array}$ & $\begin{array}{l}\text { İngilizce Erek Metin } \\
\text { Dolaylı Özde Çeviri }\end{array}$ & $\begin{array}{l}\text { Türkçe Erek Metin } \\
\text { Aslına Çeviri }\end{array}$ \\
\hline Citadelle de Saint-Jean-d'Acre & Citadel of Saint-Jean-d'Acre & Akka Kalesi \\
\hline Widdin & Widdin & Vidin \\
\hline Stamboul & Stamboul & İstanbul \\
\hline
\end{tabular}


890 / RumeliDE Journal of Language and Literature Studies 2020.S8 (November)

An act of translation in the author's mind: The source text as a product of watermark translation and its retro-translation / D.

Tuna (pp. 882-904)

\begin{tabular}{|c|c|c|}
\hline Janina & Janina & Yanya \\
\hline Épire & Epirus & Epir \\
\hline Thesprotie & Tesprotia & Tesprotya \\
\hline Thessalie & Tessaly & Tesalya \\
\hline Laconie & Laconia & Lakonya \\
\hline Turquie & Turkey & Türklerin ülkesi \\
\hline Corfou & Corfu & Korfu \\
\hline Mont Saint-Salvador & Mount San Salvador & Saint-Salvador \\
\hline Voïoussa & Vojutza & Vyosa \\
\hline Aoüs & Aous & Aous \\
\hline Conitza & Conitza & Koniçe \\
\hline Bérat & Serat & Berat \\
\hline Toscaria & Toscaria & Toskalık \\
\hline Kormovro & Kormovo & Kurmovo \\
\hline Kardiki & Kardiki & Gardik \\
\hline Argyro-Castron & Argyro-Castron & Ergiri \\
\hline Nègrepont & Negropont & Eğriboz \\
\hline Chaîne du Pinde & Pindus chain of mountains & Pindos dağları \\
\hline Delvino & Delvino & Delvine \\
\hline Monts Acrocérauniens & Acroceraunian Mountains & Keravniya dağları \\
\hline Monastir & Monastir & Manastır \\
\hline Zapourie & Zapouria & Zapurya \\
\hline Buthrotum & Buthrotum & Butrint \\
\hline Lac Pelode & Lake Reloda & Pelode Gölü \\
\hline Vallée du Pénée & Valley of the Peneus & Pinios vadisi \\
\hline Tricala & Trikala & Tirhala \\
\hline Défilés de la Perrébie & Defiles of the Perrebia & Perrebia geçitleri \\
\hline Tempé & Vale of Tempe & Bababoğazı vadisi \\
\hline Thermopyles & Termopylae & Termofil geçidi \\
\hline Avlone & Avlone & Avlonya \\
\hline Zagori & Zagori & Zagori \\
\hline Cleïsoura & Clerisoura & Kilisora \\
\hline Parga & Parga & Parga \\
\hline Prévésa & Prevesa & Preveze \\
\hline Montagnes de la Selleïde & Selleid mountains & Suli dağları \\
\hline Monastère des SS. Anargyres & Monastery of Saints-Anargyres & Anargiri Azizleri Manastırı \\
\hline Plichivitza & Plikivitza & Plişiviça \\
\hline Phocide & Phocis & Fokis \\
\hline Étolie & Mtolia & Etolya \\
\hline
\end{tabular}

Adres 1 Address 


\begin{tabular}{|c|c|c|}
\hline Acarnanie & Acarnania & Akarnanya \\
\hline Morée & Morea & Mora \\
\hline Lépante & Lepanto & İnebahtı \\
\hline Illyrie & Illyria & İlirya \\
\hline Chenderia & Chenderia & Şendriya \\
\hline Scodra & Scodra & İşkodra \\
\hline Aulide & Aulis & Aulis \\
\hline Romélie & Roumelia & Rumeli \\
\hline Débres & Delres & Debre \\
\hline Dodone & Dodona & Dodona \\
\hline Tomoros & Tomoros & Tomor \\
\hline Agia & Agia & Agia \\
\hline Golfe Ambracique & Gulf of Ambracia & Ambrakya Körfezi \\
\hline Galaxidi & Galaxidi & Galaksidi \\
\hline Nicopolis & Nicopolis & Nicopolis \\
\hline Pointe du Pancrator & Cape Pancrator & Pankrator Burnu \\
\hline Mecque & Mecca & Mekke \\
\hline Îles Ioniennes & Ionian Isles & İyon adaları \\
\hline Patras & Patras & Patras \\
\hline Arta & Arta & Narda \\
\hline Drama & Drama & Drama \\
\hline Axius & Axius & Vardar nehri \\
\hline Mont Athos & Mount Athos & Athos dağ \\
\hline Valachie & Wallachia & Eflak \\
\hline Moldavie & Moldavia & Boğdan \\
\hline Thrace & Thrace & Trakya \\
\hline Macédoine & Macedonia & Makedonya \\
\hline Leucade & Leucadia & Lefkada \\
\hline Levant & Levant & Levant \\
\hline Larisse & Larissa & Yenişehir \\
\hline Odessa & Odessa & Odessa \\
\hline Rapcani & Rapehani & Rapsani \\
\hline Constantinople & Constantinople & İstanbul \\
\hline Mosquée de Sainte-Sophie & Mosque of Saint-Sophia & Ayasofya Camii \\
\hline Îles de l'Archipel & Archipelago & Egedeki takımadalar \\
\hline Hellade & Hellas & Yunanistan \\
\hline Vélas & Velas & Köprülü \\
\hline Toxides & Toxidae & Toskalık \\
\hline Iapyges & Tapazetae & Laplik \\
\hline
\end{tabular}


892 / RumeliDE Journal of Language and Literature Studies 2020.S8 (November)

An act of translation in the author's mind: The source text as a product of watermark translation and its retro-translation / D. Tuna (pp. 882-904)

\begin{tabular}{|l|l|l|}
\hline Chamides & Chamidae & Çamlık \\
\hline Ochrida & Ochrida & Ohri \\
\hline Canina & Cannia & Kanina \\
\hline Prémiti & Premiti & Permedi \\
\hline Port Panorme & Port of Panormus & Panormus limanı \\
\hline Santi-Quaranta & Santi-Quaranta & Ayasaranda \\
\hline Sderli & Sderli & Sideri \\
\hline Paramythia & Paramythia & Aydonat \\
\hline Cinq-Puits & Five Wells & Beşpinar \\
\hline Musaché & Musache & Muzake \\
\hline Mougliana & Mongliana & Monliana \\
\hline Sponga & Sponga & Sponga \\
\hline Croie & Croie & Kroya \\
\hline Mont Paktoras & Mount Paktoras & Paktoras Dağı \\
\hline Letharitza & Lithoritza & Lithariça \\
\hline Dgéleva & Dgeleva & Celeva \\
\hline Salonique & Salonica & Selanik \\
\hline Alep & Aleppo & Halep \\
\hline Château de Kiapha & Fort of Kiapha & Kiafa şatosu \\
\hline Téka & Tika & Teka \\
\hline Franghia & Frangistan & Frengistan \\
\hline Loutcha & Loutcha & Luça \\
\hline Gréveno & Greveno & Grevena \\
\hline Sagaris & Sagaris & Sakarya nehri \\
\hline Pursak & Pursak & Porsuk çayı \\
\hline Khoutaieh & Koutaieh & Kütahya \\
\hline & & \\
\hline
\end{tabular}

Bir önceki bölümde vurgulandığı gibi, hikâyenin geçtiği topraklar bugün sınırları yeniden çizilmiş bir coğrafyadır. Bunun doğal bir sonucu olarak, Tablo 3’te yer alan yer adlarının bir çoğu günümüzde geçerli değildir. Geçerliliğini koruyanlar da Fransızca trankripsiyonla ya da Fransızcada ifade ediliş şekilleriyle anılmış olup, Türkçede tam olarak nasıl yer aldıklarını her şekilde araştırmak gerekmektedir. Örneğin, Akka Kalesi, Eğriboz, Keravniya Dağları, Vardar Nehri, Yenişehir, Aydonat gibi yer adları, Fransizca metinde sirasiyla Citadelle de Saint-Jean-d'Acre, Nègrepont, Monts Acrocérauniens, Axius, Larisse, Paramythia olarak, birbirine benzer olmayan bir şekilde geçmektedir. Buna karşılık, sessel yönden benzeşen yer adları da mevcuttur. Örneğin, Osmanlı coğrafyası dahilinde Yanya, Butrint, Fokis, Celava olarak ifade edilen yer adları, kaynak metinde Janina, Buthrotum, Phocis, Dgéleva olarak geçmektedir. İki dildeki bu örnekler sessel olarak örtüşmekte ya da benzeşmekle birlikte, böyle olduklarını saptamak için araştırma ve sağlama yapmak gerekmektedir. Bu durum, özde çeviri metnini aslına çevrilmesi noktasında çevirmenin farklı bir sorumluluk üstlenmek durumunda olmasından kaynaklanmaktadır. Diğer yandan, dolaylı özde çeviri metninde bu türden bir kaygının söz konusu olmadığı söylenebilir. Bu noktada, İngilizce erek metinde yer adları ya Fransızca kaynak metinde olduğu gibi aktarılmış, ya da transkripsiyon İngilizce okunuşa uygun olarak 
düzenlenmiştir. Özde çeviride yer alan Bérat, Lac Pelode, Iapyges, Étolie gibi adların dolaylı özde çeviriye sırasıyla Serat, Lake Reloda, Tapazetae, Mtolia şeklinde aktarılmaları bu durumun istisnaları olup, bu örneklerde muhtemelen yazım hatası söz konusu olabilir.

\section{Fransızca kaynak ve İngilizce erek metinlerde yer alan Türkçe sözcükler}

Fransızca kaynak metin ile ilgili dikkat çeken önemli bir unsur, Osmanlılara özgü kimi askeri ya da dini unvan veya terimlerin Türkçede olduğu gibi korunarak metne trankripsiyon ile aktarılmış olmasıdır. Kaynak metinde bu ifadelerin bir çoğuna yönelik olarak herhangi bir açıklama da bulunmamaktadır. Bu ifadeleri aslına çeviri bağlamında Türkçeye aktarma noktasında bir sorun söz konusu olmamakla birlikte, Fransızca metinde birer yabancı kelime olarak kalmış bu ifadelerin kaynak metin okurlarına ne ifade etmiş olabileceği de akla gelen bir sorudur. Örneğin, Rumeli valisi tamlaması aslında Fransızca olarak ifade edilebilecekken "Rouméli-Valicy" şeklinde ikinci sözcükteki iyelik eki dahi korunarak aktarılmış ve böylelikle kaynak metin okuru açısından anlaşılması pek de mümkün görünmeyen bir şekilde sunulmuştur.

Tablo 4. Fransızca kaynak ve İngilizce erek metinlerdeki Türkçe sözcükler

\begin{tabular}{|c|c|c|}
\hline $\begin{array}{l}\text { Fransızca Kaynak Metin } \\
\text { Özde Çeviri }\end{array}$ & $\begin{array}{l}\text { İngilizce Erek Metin } \\
\text { Dolaylı Özde Çeviri }\end{array}$ & $\begin{array}{l}\text { Türkçe Erek Metin } \\
\text { Aslına Çeviri }\end{array}$ \\
\hline pachas & pachas & paşalar \\
\hline beys & beys & beyler \\
\hline cadis & cadis & kadılar \\
\hline sangiaks & sanjaks & sancaklar \\
\hline Rouméli-Valicy & Roumeli-valicy & Rumeli Valisi \\
\hline yataghan & yataghan & yatağan \\
\hline Fatahat & Fatahat & Fatiha \\
\hline dervendgi-pacha & dervendgi-pacha & derbentler başbuğu \\
\hline arpalik & "arpalık" & arpalık \\
\hline icoglan & eunuch & içoğlan \\
\hline capidgi-bachi & "kapidgi-bachi" & kapıcıbaşı \\
\hline tchoadars & guards & çuhadarlar \\
\hline pacha & pacha & paşa \\
\hline oulémas & ulemas & ulema \\
\hline derviches & derviches & dervişler \\
\hline fermanly & a sentence & fermanlı \\
\hline cara (noir) & kara or black & kara \\
\hline gazi & ghazi & gazi \\
\hline Véli-Zadé & Veli-Zade & Velizade \\
\hline sérasker & seraskier & serasker \\
\hline iman & imaun & imam \\
\hline éblis & eblis & iblis \\
\hline baïram & bairam & bayram \\
\hline
\end{tabular}




\begin{tabular}{|l|l|l|}
\hline kiaïa & kiaia & kahya \\
\hline sélaou-aga & selaon-aga & selam ağası \\
\hline mousselim & mussulman & müsellim \\
\hline
\end{tabular}

Tablo 4’te görüldüğü üzere Fransızca kaynak metinde Türkçe olarak kullanılan bu sözcük ve ifadelerin birçoğu İngilizce erek metne de yer yer İngilizceye uygun transkripsiyonla aynı şekilde yansıtılmış, ancak Fransızca kaynak metindeki "icoglan" sözcüğü için eunuch, [haremağası], "fermanly" sözcüğü için a sentence [bir ceza] karşılıkları tercih edilmiştir. Bu noktada, anlamı muhtemelen anlaşılmayan bu sözcükler için çevirmenin bir yorumda bulunduğu düşünülebilir. Öte yandan, "arpalık" ve "kapidgibachi” sözcükleri tırnak içine alınırken, metinde Türkçe bırakılan diğer sözcüklerde tırnak kullanılmamıştır.

İngilizce erek metinde dikkat çeken farklı bir aktarım da, Fransızcaya "mousellim" olarak nakledilen müsellim sözcüğünün Müslüman şeklinde algılanarak "mussulman" şeklinde yansıtılmasıdır. Farklı bir örnek olarak, kaynak metinde İşkodra vezirinden Gara Bazaklia olarak söz edilmiştir. Bu Fransızca transkripsiyon Türkçe üzerinden düşünüldüğünde kulağa "Kara Bacaklı" gibi yansımaktadır. Yazar bu ismi transkripsiyona muhtemelen duyduğu ya da başvurduğu kaynaklarda geçtiği şekliyle aktarmış olup, sesi yazıya naklederken bir şekilde hata oluşmuş gibi görünmektedir zira söz etmek istediği şahsiyetin Buşatlı (ya da Bushati) ailesine mensup Kara Mahmud Paşa ${ }^{8}$ olması muhtemeldir. Ancak bu sözcüklerin olası Fransızca transkripsiyonu kaynak metinde yer alandan farklıdır. Benzer şekilde Fransızca kaynak metinde yer alan Türkçe aktarımların transkripsiyonları genellikle Türkçeyle uyumlu olsa da, imam ve selam ağası için kullanılan "iman" ve "sélaou-aga" örnekleri de bir ölçüde bunun istisnası olarak görünmektedir.

"Yabancı kentler ve uzamlar, yabancı tarihsel ve toplumsal gerçeklikler, yabancı kişiler ile bunları temsil eden özel ad göstergeleri üzerine kurulmuş özde çeviri metni okurda rahatllkla bir özgün eser değil de bir çeviri eser okuduğu düşüncesini uyandırabilir” (Öztürk Kasar, 2020: 3). Tüm bunlara ilaveten Türkçe olarak bırakılmış sözcükler, kaynak metnin özde çeviri niteliğinin pekişmesini sağlamaktadır.

\section{5. Özde çeviri, dolaylı özde çeviri ve aslına çeviri bağlamında metinlerarası unsurların aktarılması}

Metinlerarasılık, "bir metnin yazarının o metin ve diğer metinler arasında kurduğu dilsel veya izleksel ilişki” (Boztaş \& Okyayuz Yener, 2005: 78) olarak tanımlanabilir. "Böylece bu metinle diğer metinler arasında bir bağdaşıklık, gönderimsel ve bağımlı bir ilişki kurulur” (Boztaş \& Okyayuz Yener, 2005: 78). Metinlerarasılık ilişkisi alıntı ya da gönderge yoluyla açık bir şekilde kurulabileceği gibi, anıştırma yoluyla kapalı olarak da kurulabilir (Aktulum, 2007: 94). Ali Pacha, temelde tarihi bir roman olarak anılmakla birlikte, farklı metin ve alanlarla ilişkide olan zengin bir ağla örülmüsstür. Bu ağ, ciddi araştırma gerektiren, çeviriye ve çevirmene meydan okuyan, tam anlaşılmayan ya da anlaşılmakla birlikte aktarılmaya direnen metinlerarası unsurlar içermektedir. Bunlardan bazıları, "bir tür kapalıanlatım, kapalı-sezdirim yolu” (Aktulum, 2007: 111) olarak anıştırma formatındadır. Anıştırma söz konusu olduğunda, "düzanlam altından söyleme ait bir yananlam çlkar" (Aktulum, 2007: 113). Pierre Fontanier ise anıştırmayı "tarihle ilişkisi olursa 'tarihsel'; masalla olursa 'söylensel'; gelenek görenek, inançlarla ilgili olursa 'töresel', yalnızca söz oyunlarına dayanırsa 'sözsel”' (Aktaran: Aktulum,

8 Türkiye Diyanet Vakfı İslam Ansiklopedisi. https://islamansiklopedisi.org.tr/mustafa-pasa-busatli [23.03.2020].

Adres

Kurklareli Üniversitesi, Fen Edebiyat Fakültesi, Türk Dili ve Edebiyat Bölümü, Kayalı Kampüsü-Kırklareli/TÜRKIYE e-posta: editor@rumelide.com 
2007:110-111) olarak tanımlamıştır. Ali Pacha, tarihi, askeri, siyasi, dini, coğrafi, sosyolojik ve kültürel unsurların iç içe geçtiği karma nitelikli bir özde çeviri metindir. Böyle bir metni çevirmek için ön koşul, kapsamlı bir çözümleme yapmaktır. Öte yandan, metni aslına döndürmek üzere yapılan bir çeviride, çevirmeni daha ayrıntılı bir araştırma yükümlülüğünün beklediği söylenebilir.

\subsection{Metni karma nitelikli kılan metinlerarası unsurlar ve çeviri süreçleri}

Bu bölümde, özde çeviri metni olarak ele aldığımız kaynak metinde yer alan metinlerarası unsurların aslına çeviri süreci ile ilgili örneklere yer verilmekte ve aslına çeviri metni ile dolaylı özde çeviri metni karşlaştırmalı olarak incelenerek aslına çeviri sürecine yönelik bilgiler aktarılmaktadır. Metinde yer alan tarihi, askeri, siyasi, dini, coğrafi, sosyolojik ve kültürel unsurlar çoğu zaman iç içe geçmiş olduğundan, ele alınan bölümler için metinlerarası unsurlar temelinde bir sınıflandırma yapılmamış, örnekler kitapta yer alma sıralarına göre dizilmiştir.

\section{Örnek 1}

Özde çeviri: On se rassemble en tremblant ; on entonne le chant sacré du Fatahat, et le meurtre est déclaré légal, au nom du Dieu clément et miséricordieux, souverain des mondes (Dumas, 1840: 22).

Dolaylı özde çeviri: They assembled, trembling; the sacred hymn of the Fatahat was sung, and the murder declared legal, in the name of the merciful and compassionate God, Lord of the World (Dumas, 2004: $\mathrm{mxx}$ ).

Aslın çeviri: Korkudan titrenerek toplanıldı, Fatiha okundu ve cinayet âlemlerin rabbi, rahman ve rahim Allah'ın adına meşru ilan edildi (Dumas, 2020: 25).

$\mathrm{Bu}$ örnekte, bütün entrikalarına rağmen, Delvine sancağının kendisine değil de, Selim Paşa'ya verilmesine içerleyen Ali, Selim’in güvenini kazanır, sarayına kabul edilir ve sonunda ona komplo kurarak padişahtan Selim’in ölüm fermanını almayı başararak onu öldürtür. Daha sonra infaza ilişkin tutană̆ı düzenlemek üzere kadı efendinin, beylerin ve Rum arkhonların saraya gelmelerini emreder. Özde çeviri metninde Fatiha suresi Fransizca transkripsiyonla "Fatahat" olarak yer almakta olup, dolaylı özde çeviri metnine de aynı şekilde aktarılmıştır. İslam dini ile metinlerarası bir bağlantı içeren bu bölümün aslına çevrilmesinde sözcük seçiminin bağlama uygun olmasına dikkat edilmiş ve "âlemlerin rabbi, rahman ve rahim Allah" ifadesi kullanılmıştır.

\section{Örnek 2}

Özde çeviri: le pacifique Sélim, tiré de la prison où entraient ses neveux, pour monter sur le trône de son frère, confirma le pacha de Janina dans les titres, charges et privilèges qui lui avaient été (Dumas, 1840: 27)

Dolaylı özde çeviri: the peaceful Selim, exchanging the prison to which his nephews were now relegated, for the throne of their father, confirmed the Pacha of Janina in the titles, offices, and privileges which had been conferred on him (Dumas, 2004: mxxiv)

Aslına çeviri: Ağabeyinin tahtına çıkmak için yeğenlerinin girdiği hapisten çıkan barışçı Selim, Yanya Paşası'nı unvan, yükümlülük ve imtiyazlarıyla birlikte tasdik etti (Dumas, 2020: 32).

Kitabın bu bölümünde, Osmanlı tarihinde gerçekleşen bir padişah değişikliğinden ve bu değişikliğin Ali’ye hiçbir şey kaybettirmediğinden söz edilmektedir. Ancak cümlede bir bilgi hatası mevcuttur. Sultan I. Abdülhamit, III. Selim’in ağabeyi değil amcasıdır. Bu nedenle burada söz konusu olan, III. Selim'in aslında "amcasının" tahtına çıkmak için, "kuzenlerinin" girdiği hapisten çıkmasıdır. Bu bölüm, dolaylı çeviri ve aslına çeviri metinlerine bilgi hatası korunarak aktarılmış, ancak aslına çeviri metnine konuyla ilişkin bir dip not eklenmiştir. 
An act of translation in the author's mind: The source text as a product of watermark translation and its retro-translation / D. Tuna (pp. 882-904)

Örnek 3

Özde ceviri: Le divan, comprenant enfin qu'il fallait en finir à tout prix avec un homme aussi dangereux, récapitula tous les attentats, et prononça contre lui la sentence de Fermanly, qui fut ratifiée par une bulle du grand muphti (Dumas, 1840: 86).

Dolaylı özde çeviri: The Divan, comprehending at last that so dangerous a man must be dealt with at any cost, recapitulated all Ali's crimes, and pronounced a sentence against him which was confirmed by a decree of the Grand Mufti (Dumas, 2004: mlxv).

Aslına çeviri: Bu kadar tehlikeli bir adamdan ne pahasına olursa olsun kurtulmak gerektiğine nihayet kanaat getiren Divan, Ali'nin saldırılarının bir dökümünü çıkarıp onu fermanlı olarak cezaya çarptırdı; Şeyhülislam da cezayı fetva vererek tasdik etti (Dumas, 2020: 93).

Ali Paşa'nın çarptırıldığı ceza, özde çeviri metninde Türkçe olarak Fransızca transkripsiyonla "Fermanly" olarak yer almakta olup, bu konuda herhangi bir açıklamaya yapılmamıştır. Dolaylı özde çeviri metinde bu sözcüğe yer verilmemiş, yerine "a sentence" [bir ceza] ifadesi kullanılmıştır. "Fermanlı" sözcüğü günümüzde kullanımda olmadığından, aslına çeviri metnine "hükümete karşı gelmek suçuyla aranan ve cezalandırılması için hakkında ferman çıkan kimse"9 şeklinde dip not düşülmüştür.

\section{Örnek 4}

Özde çeviri: Elle portait -qu'Ali Tébélen, après avoir obtenu à diverses reprises, le pardon de ses félonies, venait encore de commettre le crime de lèse-majesté au premier chef, et qu’il serait mis, comme relaps, au ban de l'empire, s'il ne se présentait au seuil doré de la porte de félicité du monarque, qui dispense les couronnes aux princes qui règnent dans le monde, dans le délai de quarante jours, pour s'y justifier (Dumas, 1840: 86-87).

Dolaylı özde çeviri: It set forth that Ali Tepelen, having many times obtained pardon for his crimes, was now guilty of high treason in the first degree, and that he would, as recalcitrant, be placed under the ban of the Empire if he did not within forty days appear at the Gilded threshold of the Felicitous Gate of the Monarch who dispenses crowns to the princes who reign in this world, in order to justify himself (Dumas, 2004: mlxv).

Aslına çeviri: Buna göre, yaptığı hainlikler için defalarca affa mazhar olan Tepedelenli Ali şimdi de padişaha karşı suç işlemiş̧i. Dünyayı yöneten prenslere tacü taht tevzi eyleyen Bâbüssaâde'nin altın yaldızlı eşiğinde kendini temize çıkarmak üzere kırk gün içinde hazır bulunmazsa, itaatsizliği nedeniyle imparatorluktan sürülecekti (Dumas, 2020: 93).

Ali Paşa'nın Divan tarafından çarptırıldığı cezanın anlatıldığı bu bölümün aslına çevrilmesinde betimlemelerin ve sözcük seçiminin anlatının geçtiği zamana ve bağlama uygun olmasına dikkat edilmiştir. Özde çeviri metniyle aslına çeviri metninin yayınlanması arasında 280 yl geçtiği dikkate alındığında, bu durumun çevirmene farklı bir sorumluluk yüklendiğinden söz edilebilir. Diğer yandan, dolaylı özde çevirinin tanımı ve doğası gereği İngilizce erek metin bağlamında bu türden bir durumun söz konusu olmadığı söylenebilir.

\section{Örnek 5}

Özde çeviri: Comme il ouvrait un jour le Koran, pour le consulter sur son avenir, sa baguette divinatoire s'arrêta sur le verset 82 du chapitre XIX où il est dit : - Il se flatte vainement. Nous écrirons son ostentation et nous aggraverons ses peines. Il paraîtra nu devant notre tribunal (Dumas, 1840: 87).

Dolaylı özde çeviri: As he one day opened the Koran to consult it as to his future, his divining rod stopped at verse 82, chap. xix., which says, "He doth flatter himself in vain. He shall appear before our tribunal naked and bare." (Dumas, 2004: mlxv).

Aslına çeviri: Bir gün geleceği hakkında Kuran’a başvurarak tefeül etti. Kullandığı çatal çubuk 19. surenin 82. ayetinde durdu. Orada şöyle denmekteydi: "O (kâfir), gaybı mı bildi? Yoksa Rahmân

Türk Dil Kurumu Güncel Türkçe Sözlük. https://tdk.gov.tr/ [20.01.2019].

Kurklareli University, Faculty of Arts and Sciences, Department of Turkish Language and Literature, Kayalı Campus-Kırklareli/TURKEY e-mail: editor@rumelide.com 
(olan Allah) katından bir söz mü aldı? Hayır, asla öyle değil; biz onun söylediklerini yazacağız ve azabını çoğalttıkça çoğaltacağız. O söylediği (mal ve evlat gibi) şeyleri de hep elinden alacağız ve o, tek başına bize gelecektir” (Dumas, 2020: 93-94)

Bu bölümde divan tarafından fermanlı olarak cezaya çarptırılan Ali, İstanbul'a hediyeler ve yalvarıp yakarmalı arzuhâller gönderir; ancak hiçbiri işe yaramaz. Padişah, her kim Ali'den söz ederse kellesini vurdurmaya yemin etmiştir; bu nedenle bunları padişaha ulaştırmaya kimse cesaret edemez. Hiçbir cevap alamayan Ali derin kaygıların pençesine düşer ve geleceği hakkında bir ipucuna rastlamak amacıyla Kuran'dan rastgele bir sayfa açarak, elindeki çatal çubuğun denk geldiği yeri okur. Özde çeviri metninde tarif edilen bu eylemin aslı "tefeül etmek" olarak geçmektedir. Bu nedenle metin aslına çevrilirken, bu ifadeye yer verilmiştir. Diğer yandan, özde çeviride yer verilen ayet, Fransızca kaynak metinden çevrilmemiş olup, yerine Kuran'ın farklı mealleri incelenmiştir. Ancak, bu inceleme sonucunda, 19. surenin 82. ayetinin kaynak metinde yer verilenden farklı bir içerikte olduğu görülmüştür. Yapılan araştırmada, alıntının içerik ve bağlam yönünden 19. surenin 79 ve 80 . ayetlerine kısmen uyduğu görülmüş, ancak alıntının bütünlüğü açısından başına 78 . ayet de ilave edilip Elmalılı Muhammet Hamdi Yazır'dan alınan tefsir kullanılarak bu yönde not düşürmüştür. Dolaylı özde çeviri metninde ise özde çeviride kullanılan tercümenin bir kısmına yer verilmiştir.

\section{Örnek 6}

Özde çeviri: Il avait fait mettre sur le pied de guerre Ochrida, Avlone, Canina, Bérat, Cleïsoura, Prémiti, le port Panorme, Santi-Quaranta, Buthrotum, Delvino, Argyro-Castron, Tébélen, Parga, Prévésa, Sderli, Paramythia, Arta, le poste des Cinq-Puits, Janina et ses châteaux (Dumas, 1840:9394).

Dolaylı özde çeviri: He had fortified and supplied with munitions of war Ochrida, Avlone, Cannia, Berat, Cleisoura, Premiti, the port of Panormus, Santi-Quaranta, Buthrotum, Delvino, Argyro-Castron, Tepelen, Parga, Prevesa, Sderli, Paramythia, Arta, the post of the Five Wells, Janina and its castles (Dumas, 2004: mlxx).

Aslına çeviri: Ohri, Avlonya, Kanina, Berat, Kilisora, Permedi, Panormus limanı, Ayasaranda, Butrint, Delvine, Ergiri, Tepedelen, Parga, Preveze, Sideri, Aydonat, Narda, Beşpınar mevkii, Yanya ve kalelerini savaş düzenine sokmuştu (Dumas, 2020: 100).

Yer adları bir edebi metinde doğal olarak yer alan ve aktarımları çoğunlukla güçlük arz etmeyen özel adlardır. Öte yandan, yer adlarının çevirisini konu alan bölümde ifade edildiği üzere, evvel zaman içinde var olmuş ve sınırları günümüzde yeniden çizilmiş bir uzamda geçen coğrafi unsurları çevirmek özel bir çalışma gerektirmektedir. Kaynak metnin özde çeviri niteliğini taşıdığı durumlar söz konusu olduğunda ise yer adlarını aslına döndürme yükümlülüğü çevirmen açısından ek bir sorumluluk olarak ortaya çımaktadır. Yukarıdaki Fransızca özde çeviri ve İngilizce dolaylı özde çeviri örnekleri karşılaştırmalı olarak incelendiğinde, yer adlarının her iki metinde de hemen hemen aynı olduğu görülmektedir. Diğer yandan, Türkçe aslına çeviri metninde bu adlar farklı şekilde ifade edilmiştir. Farklı bir örnek olarak, aslına Beşpınar mevkii olarak çevrilen yer adı, kaynak metinde "Beş Kuyular" anlamına gelen Cinq Puits şeklinde ifade edilmiştir. Çoğu örnekte söz konusu yer adlarına endonimegzonim bağlamında bakmak yeterli olmayıp, eski haritalar da dahil olmak üzere farklı kaynaklardan araştırma yapmak ve elde edilen verileri teyit etmek gerekmektedir. Bu tür bir çalışma, özellikle köy ya da kasaba adları gibi küçük yerleşim yerlerinin adlarını aslına döndürme noktasında yer yer zorlu bir nitelik kazanmaktadır.

\section{Örnek 7}

Özde çeviri: Ces places contenaient quatre cent vingt canons de tout calibre, la plupart en bronze, montés sur des affûts de siège, et soixante-dix mortiers. Il y avait en outre, dans le château du lac, indépendamment de l'artillerie de position, quarante pièces de campagne, soixante de montagne, une masse de fusées à la Congrève, données autrefois par les Anglais, et une énorme quantité de 
An act of translation in the author's mind: The source text as a product of watermark translation and its retro-translation / D. Tuna (pp. 882-904)

munitions de guerre. Enfin, on travaillait à établir une ligne de sémaphores, depuis Janina jusqu’à Prévésa, pour avoir rapidement des nouvelles de l'escadre ottomane, qui devait paraître de ce côté (Dumas, 1840: 94).

Dolaylı özde çeviri: These places contained four hundred and twenty cannons of all sizes, for the most part in bronze, mounted on siege-carriages, and seventy mortars. Besides these, there were in the castle by the lake, independently of the guns in position, forty field-pieces, sixty mountain guns, a number of Congreve rockets, formerly given him by the English, and an enormous quantity of munitions of war. Finally, he endeavoured to establish a line of semaphores between Janina and Prevesa, in order to have prompt news of the Turkish fleet, which was expected to appear on this coast (Dumas, 2004: mlxx).

Aslına çeviri: $\mathrm{Bu}$ yerlerde, top kundaklarına monte edilmiş, çoğu bronz, her kalibreden dört yüz yirmi top ile yetmiş havan topu mevcuttu. Bunun haricinde, ateşe hazır ağır silahlardan bağımsız olarak göl şatosunda kırk sahra topu, altmıș dağ topu ve bir zamanlar İngilizler tarafından verilen bir yığın Congreve roketiyle mebzul miktarda mühimmat vardı. Son olarak, Yanya'dan Preveze'ye kadar bir semafor hattı kurmak için çalışlıyordu; amaç bu taraftan zuhur edecek Osmanlı filosundan ivedilikle haberdar olmaktı (Dumas, 2020: 100).

Bu bölümde, kaynak metnin askerlik alanı ile bağlantısını örnekleyen metinlerarası unsurlar yer almaktadır. Karma nitelikli bir metinde çevirmenin karşısına çıkabilecek terimlere örnek teşkil eden bu bölüm, çevirmenin doğrudan ilgi ya da çalışma alanına dahil olmayan bir alanda çeviri yaparken geçeceği süreçleri yansıtması açısından önem taşımaktadır. Kaleme alınma tarihi eski olan bir metin söz konusu olduğunda yapılacak araştırmanın daha incelikli bir zeminde yürütülmesi zorunluluğu da ortaya çlkmaktadır. Bu bölüm, çevirmenin sözlüklere başvurmakla yetinemeyeceği durumlara örnek oluşturduğundan ayrıca dikkate değer bir örnektir. Özde çeviri ve dolaylı özde çeviri metinlerine bakıldığında, terimlerin yer yer aynı şekilde ifade edildiği görülmekte olup, Batı dillerindeki ortak söz varlığı bu diller arasında yapılan çevirilerde çevirmenin lehine işleyen bir durum olarak nitelendirilebilir.

\section{Örnek 8}

Özde çeviri: Un marabout lança ensuite une pierre du côté du château, et l'anathème contre le noir Ali fut répété par toute l'armée turque, qui le termina par les cris de : Vive le sultan! Ainsi soitil! (Dumas, 1840: 98-99).

Dolaylı özde çeviri: A Marabout then cast a stone towards the castle, and the anathema upon "Kara Ali" was repeated by the whole Turkish army, ending with the cry of "Long live the sultan! So be it!" (Dumas, 2004: mlxxiii)

Aslına çeviri: Arkasından bir murabıt kaleye doğru bir taş attı ve Kara Ali tüm Türk ordusu tarafından tekrar tekrar lanetlendi, tezahürat "Padişahım çok yaşa! Amin!” nidalarıyla sona erdi (Dumas, 2020: 105).

Bu örnekte, cezaya çarptırıldığı için "kara" sıfatı ile anılacak olan Ali'ye okunan lanetlerden sonra, padişaha yönelik övgü tezahüratları yapılmakta olup, Türkçe çeviride tezahüratlar bağlamla uyumlu olacak şekilde aslına döndürülmüştür.

\section{Örnek 9}

Özde çeviri: Afin d'opérer une diversion, ils devaient descendre de nuit dans le vallon de Janina, occuper une position qu'il leur indiquait, et il leur donnait pour signe de reconnaissance le mot d'ordre flouri (Dumas, 1840: 106)

Dolaylı özde çeviri: In order to cause a diversion, they were to descend into the valley of Janina at night, and occupy a position which he pointed out to them, and he gave their the word "flouri" as password for the night (Dumas, 2004: mlxxviii-mlxxix).

Aslına çeviri: Bir șaşırtma harekâtı gerçekleștirmek için geceleyin Yanya vadisine inip Ali'nin kendilerine gösterdiği mevkiyi işgal etmeleri lazımdı. Ali teşhisi sağlamak açısından flouri kelimesini parola olarak belirlemişti (Dumas, 2020: 114). 
Metnin bu bölümünde Ali Paşa, Fransızca kaynak metinde geçtiği şekliyle flouri sözcüğünü Suliyotlarla arasında bir parola olarak belirlemektedir. Sözcük, metinde yalnızca parola olarak geçtiği için bağlamdan anlamı tahmin etme gibi bir olasılık söz konusu değildir. Bu sözcük, İngilizce çeviride de kaynak metinde olduğu gibi bırakılmıştır. Bu noktada, sadece bir parola olmasına rağmen metnin anlam evrenine bir katkısı olabileceği düşünülerek sözcüğün anlamı araştırılmıştır. Kaynak metnin Fransızca olmasından dolayı öncelikle birçok kaynaktan sözcüğün Fransızca bir anlamı olup olmadığına bakılmıştır. Daha sonra, anlatının geçtiği Arnavutluk-Yunanistan coğrafyası ile parolanın

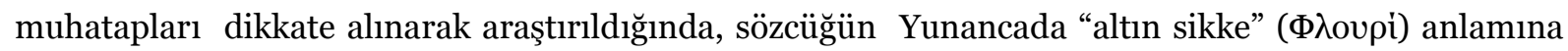
geldiği ve kaynak metindeki Fransızca transkripsiyonla aynı şekilde okunduğu bilgisine ulaşılmıştır. Diğer yandan İtalyanca filorin sözcüğünden gelen ve Osmanlıcaya yine aynı "altın sikke" anlamıyla yerleşen "filori” de okunuştaki küçük farka karşın aynı sözcüktür. Osmanlılar bu sözcüğü hem kendi bastıkları hem de Avrupa menşeli altın paralar için kullanmıştır. ${ }^{10}$

\section{Örnek 10}

Özde çeviri: On salua de cris de triomphe un écriteau attaché à la tête d'Ali, qui relatait ses crimes et les circonstances de sa mort, et finissait par ces mots : Et ceci est la tête dudit Tébélen Ali pacha, traitre à la foi (Dumas, 1840: 132).

Dolaylı özde çeviri: [...] triumphant shouts greeted the appearance of a document affixed to the head which narrated Ali's crimes and the circumstances of his death, ending with these words: "This is the Head of the above-named Ali Pacha, a Traitor to the Faith of Islam" (Dumas, 2004: mxcvii)

Aslına çeviri: Ali’nin kellesine iliştirilmiş bir yaftaya zafer çığllklarıyla selam durdular. Yaftada Ali’nin suçları ve nasıl öldüğü anlatıllıyor, sonunda şu sözlere yer veriliyordu: "Tepedelenli Ali Paşa dedikleri hâin-i dinin ser-i maktû'udur (Dumas, 2020: 141).

Ali Paşa'nın öldürülmesinden sonra kesik başı İstanbul'a getirilerek sergilenir. Özde çeviri metnine göre, kesik başa suçlarını ve hangi ahval içinde can verdiğini anlatan bir "écriteau" iliştirilmiştir. Bu sözcük, Fransızcada halka yönelik olarak büyük harflerle yazılmış bilgiler içeren kağıt veya tahta parçası, afiş, etiket, tabela, levha, plaka, poster, yazıt gibi anlamlar içermektedir ${ }^{11}$. Dolaylı özde çeviri metninde, bu sözcük "document” [belge] olarak aktarılmakla yetinilmiştir. Bu olayı aslına çevirmek için yapılan araştırmada, söz konusu açıklamanın yer aldığı kağıdın "yafta” olarak adlandırıldığı bilgisine ulaşılmıştır. Yaftanın içeriği kaynak metinden çevrilmek yerine doğrudan aktarılmıştır.

\subsection{Cinsiyet ayrımcılı̆̆ı ve kadına şiddet göstergelerinin aktarılması}

Ali Pacha'nın farklı metin ve alanlarla bağlantı içinde olan yoğun metinlerarası ağında kimi zaman açık ve kimi zaman da örtük olmak üzere yer alan askeri, dini, kültürel, toplumsal ve töresel unsurlar ataerkil bir şiddet zeminine oturmaktadır. Böylesi bir zeminde, erkekten kadına yönelen ve günümüzde de yansımaları halen sıcak gündem olan her çeşit zorbalığın yanı sıra, toplumun her kesimine yayılan şiddet döngüsü ve sarmalı söz konusudur.

Ali'nin annesi Hanko ve kız kardeşi Şehnisa'nın Tepedelen'den kaçrrılarak Gardik'de zindana atılmaları ve bir ay boyunca her gece farklı kişiler tarafından tecavüze maruz bırakılmaları (Dumas, 2020: 14) kadınlara yönelik fiziksel ve cinsel şiddete önemli bir örnektir. Tarih boyunca savaş, kırım, baskın ve yağma suçları genellikle tecavüz suçu ile bir arada işlenmiş ancak kitleleri kıran bu olguların neredeyse ayrılmaz bir parçası olan cinsel şiddet suçları her zaman yeterince irdelenmemiştir. Bu unsurların önemli bir bölümünde erkeklerin başka erkeklerden intikam almak için o erkeklerle bir

Türkiye Diyanet Vakfı İslam Ansiklopedisi. https://islamansiklopedisi.org.tr/filori. [22.02.2020]. Reverso Dictionnaire. https://dictionnaire.reverso.net/francais-definition/ecriteau [22.02.2020]. 
şekilde bağlantısı olan kadınlara tecavüz etmeleri söz konusudur. Bu tür örneklerde tecavüz suçunu işleyen kişiler kendilerini galip ve muzaffer görmekte, intikam alınmak istenen erkekler ise tecavüze uğratılan kadınlar üzerinden aşağılanmakta ve kadın bedeni erkekler arasındaki hesaplaşmaların nesnesi haline getirilmektedir. Buna karşllık, iftira ya da tecavüze uğrayan kadınlar hakir görülmekte, ötekileştirilip dışlanmakta, suçlu muamelesi görmekte ve kendilerini öyle hissetmeleri sağlanmakta iken, tecavüzcüler ve zorbalar da suç işledikçe daha fazla cüret kazanmaktadır.

Kitapta da cinsel şiddet unsurları ana hikâyeye yer yer serpiştirilmiş ve hayatın olağan akışı içinde adeta sıradanlaştırılarak sunulmuştur. Bu noktada kadına yönelik her tür şiddetin, yer yer sinsice sızmak, yer yer de alenen işlenmek suretiyle dünyanın her köşesine ve katmanına yayılmış olduğunu ve bu durumun edebi eserlere de bire bir yansıdığını anımsamakta yarar vardır. Bu durum, Ali Pacha gibi doğrudan kadınları konu almayan ve farklı bir odakla kurgulanmış görünen romanlar için de geçerlidir; zira "[h]er yapıt, kendini belli bir tür içinde konumlandırırken zorunlu olarak geçmişte o tür içinde konumlanmış başka yapıtları ve o türü biçimlendiren toplumsal koşulları 'anımsar”' (Irzık, 2001: 15-16). Ne yazık ki bir "toplumsal koşul" olarak kadına yönelik şiddet, tüm zamanlarda var olmuştur ve bugün de gücü elinden bırakmama derdinde olan ataerkinin tahakküm politikalarının baş unsurlarından biridir. Bu bölümde yer verilen örnekler ve bu örneklerde kullanılan dil "ideolojik yaşamın tüm alanlarında azami bir karşılıklı anlaşma sağlayan dil olarak, tıka basa ideolojiyle dolu olarak, bir dünya görüşü olarak, hatta somut bir fikir olarak” (Bakhtin, 2001: 47) kavranabilir. Aynı doğrultuda, yine Bakhtin'in deyimiyle "üniter bir dil, toplumsal-politik ve kültürel merkezileştirme süreçleriyle yaşamsal bir bağlantı içinde gelişen güçleri, yani somut dilsel ve ideolojik birleştirme, merkezileştirme doğrultusunda işlerlik gösteren güçleri dile getirir" (2001: 47). Böylelikle toplumdan metne bulaşan şiddet, metinden metne geçerek metinlerarası bir unsur niteliği kazanır ve metinler yoluyla yeniden üretilip pekiştirilerek bir döngü içinde çıkış noktası olan topluma geri döner. Ali Pacha gerçek bir hayat hikâyesi olması nedeniyle bu açıdan özel bir örnek teşkil etmektedir.

Gardik'deki tecavüz dehşetine ilişkin dikkat çekici başka bir husus da tecavüze uğrayan Hanko'dan "fahişe" şeklinde söz edilmesidir. Tüm vahametiyle günümüze kadar süregelen cinsel şiddet olgusu kapsamında saldırıya maruz kalan kadınların bu zulüm üzerinden her tür hakaret ve iftiraya uğraması ve hatta tehdit altında tekrar tekrar tecavüze maruz kalması, cinsel şiddetin çoğul bir boyutta düşünülmesini zorunlu kılmaktadır. Söz konusu bölümde Ali'den normalleştirilmiş bir üslupla "fahişenin oğlu" (Dumas, 2020: 31) diye söz edilmesi, tecavüze uğrayanlara ve onların yakınlarına yapıştırılan yaftalara sadece bir örnektir.

İftiraya uğrayan kadınlara ilişkin diğer bir örnekte, Berat veziri Kurt Paşa'nın damadı İbrahim, karısı Zaide'nin kendisini zehirleyeceğine, sonra da Ali Paşa ile evleneceğine ilişkin bir takım imzasız mektuplar alır. Bu noktada anlatıcı "Türklerin ülkesi gibi, bir kadının şüphe üzerine anında suçlandığı ve suçlandığı anda da cezaya çarptırıldığı bir yerde, böyle bir iftira masum Zaide'nin ölümüne neden olmalıydı" (Dumas, 2020: 37) yorumunda bulunur. İbrahim her ne kadar bu iftiraya itibar etmese de, bu tür durumlar yalnızca romanın geçtiği uzam ve zamanda değil, dünyanın her yerinde bugün de hala geçerli olan kadın cinayetlerine sözde "namus" kisvesi altında bahane ve kılıf teşkil etmektedir.

Başka bir örnekte ise cinsel şiddetin fiziksel şiddetle nasıl iç içe geçmiş olduğu gözler önüne serilmektedir. Anlatıcı, Ali Paşa'nın oğlu Veli'den bahisle, sefahati zulümle harmanladığından söz eder: "Onun için tam mutluluk, öptüğü dudakları ısırıklarla kanatmak, henüz okşadığı hatları tırnaklarıyla yırtmaktı. Yanya sakinleri, koynundan çıkarken burnunu ya da kulaklarını kestirdiği birden fazla kadının sokaklarda dolaştığını dehşet içinde görmüşlerdi” (Dumas, 2020: 42). Erkeklere sırf erkek 
olmalarından dolayı peşinen güç bahşedilmiş olması, bu gücün yüksek ego ve cüretlendirilmiş bir fiziksel güçle pekişerek bazı durumlarda bir de makam, mevki ve maddiyattan beslenmesi kadına yönelik şiddetin dozunun arttıkça artmasına neden olmaktadır. Bu çeşit zulümler, günümüzden birkaç asır öncesini anlatan bir romanda söz konusu olduğu gibi, bugünün şartlarında da gerek benzer gerekse evrilmiş biçimlerde sürmektedir

Kitabın ilerleyen bölümlerinde Ali Paşa annesine ve kız kardeşine tecavüz eden Gardiklileri bir handa pusuya düşürerek katlettirir. Katiller bundan sonra kente giriş yapar, evlere dağılır, kadınlara tecavüz eder ve çocukları da istismar eder (Dumas, 2020: 63). Böylelikle korkunç bir tecavüz vakasının intikamı, toplu bir tecavüz vakasıyla tamamlanır. Sonuç olarak Ali Paşa Gardiklilerin işlediği tecavüz suçunun bedelini onlara canlarıyla ödetmekte, ancak aynı suçu kendi adamlarının da kadınlara ve çocuklara yönelik olarak işlemesiyle tecavüz olgusu bir döngü halini almaktadır. Bu döngüde, erkeklerin kozlarını kadınlar üzerinden paylaşması söz konusu olduğu gibi, bu durum çatışmalarla bağlantılı cinsel şiddet olgusu üzerinden de açıklanabilir. Çatışmalarla bağlantılı cinsel şiddet, "tecavüzün yanı sıra cinsel kölelik ve fahişelik, hamilelik, kürtaj, kısırlaştırma ve evliliğe zorlanma ve benzer ağırlıktaki her tür cinsel şiddeti de içine alır."12 Bu noktada, burada anılan şiddet türlerinin sadece devlet, toplum ya da topluluklar arasındaki çatışmalarla sınırlı olmayıp, bireysel temelde de vuku bulduğundan söz etmek gerekir.

Ali Paşa, oğlu Veli'nin karısı Zübeyde'ye şiddetli bir tutku beslemektedir. Veli'nin yokluğunu firsat bilerek attığı adımlar Zübeyde tarafından geri püskürtülünce gelinine uyku veren bir içecek içirtir. Zübeyde tecavüze uğradığını ancak anne olmanın eşiğine gelince anlar. Ali suçunu itiraf edip özür diler ve bebeği ortadan kaldırmaya söz verir. Zübeyde, suçun izini ondan daha da korkunç ikinci bir suçla ortadan kaldırma fikrinden cayması için Ali'ye yalvarıp yakarır; ancak onu ikna edemez. Zübeyde'nin dairesine bir doktor gönderen Ali, onu kürtaj ettirir ve çıkışta da doktoru boğdurur (Dumas, 2020: 6769). Gerçek ya da kurgusal bağlamda aile içi cinsel şiddetin akıl almaz boyutlarına sadece bir örnek teşkil eden bu bölümde, kadına kendi bedeni üzerinde hiçbir aşamada ve hiçbir biçimde söz hakkı tanınmamaktadır. Kadına yönelik diğer şiddet türleri gibi cinsel şiddet de ne yazık ki bugün dahi farklı coğrafyalarda farklı boyutlarıyla gerek kadınların yaşadıkları evlerde gerekse ev dışı mekânlarda dünya yüzünden silinmemek adına çok çeşitli şekillerde direnç göstermektedir. Bunun bir uzantısı olarak birçok mekân cinsel şiddet tehdidi ile erkek olarak cinsiyetlendirilmekte ve böylelikle pek çok alanda kadınların özgürlüklerinin kısıtlanmasına zemin ve bahane oluşturmaktadır. Bu noktada kadınlara yönelen her bir şiddet türü, kendi türü dahilinde zarar vermekle kalmamakta, kadınların hayatlarına farklı alanlarda da kabus gibi ayrıca çökmektedir.

Parga'ya gönderdiği ordusunun zafer kazandığını zanneden Ali Paşa, generallerine haberci üstüne haberci göndererek Parga'nın kadınlarıyla kızlarını haremindeki derin zevklere tahsis edilmek üzere ayırmaları yönünde talimat verir (Dumas, 2020: 63). İstila ya da fethedilen yerlerde kadınların alıkoyulması, özgürlüklerinden mahrum bırakılması, tacize ve tecavüze uğraması, seks kölesi olarak kullanılması gibi olgular halen geçerliliğini korumaktadır. Erkek şiddeti, en gelişmiş ülkeler de dahil olmak üzere dünyanın her yerinde ataerkinin devamını sağlamak için sebat etmektedir.

Diğer yandan, hayattan metne, metinden metne, metinden hayata ve tüm zamanlardan bugüne aktarılarak ayak direyen kadına yönelik şiddet, bu metinde de karşımıza çıkmıştır. Metinde yer alan şiddet örnekleri, hiç kuşkusuz burada yer verdiklerimizle sınırlı değildir. Bundan önceki bölümlerde,

Nato review. Çatışmalarla bağlantılı cinsel şiddet. https://www.nato.int/docu/review/tr/articles/2017/10/26/ catismalarlabaglantili-cinsel-siddet/index.html [10.09.2020]. 
kaynak metnin bir özde çeviri metni olması durumunda, dolaylı özde çeviri ve aslına çeviri metinlerinde çevirmenleri bekleyen sorumlulukların farklılık gösterebileceğinden söz etmiştik. Buna karşlık, kadına şiddet söz konusu olduğunda, kaynak metinde ifade edilenlerin erek metinlere aktarılması noktasında farklı bir denklem oluşmadığından söz edilebilir; zira kadına yönelik şiddet, gerek özde çeviri metninin ait olduğu toplum ve kültür bağlamında, gerekse dolaylı özde çeviri ve aslına çeviri metinlerinin ait oldukları toplum ve kültürlerde binlerce yıldır var olan hastalıklı bir olgudur. Bu anlamda, kaynak dilde ifade edilen şiddetin, erek dillerde de ne yazık ki karşllı̆̆ı vardır. Şiddet ve cinsiyet ayrımcıllğı hayattan metne ve metinden metne nasıl aktarılıyorsa, dilden dile de aynı şekilde aktarılmaktadır.

\section{Sonuç}

"Çeviri, yazınsal ve kültürel ürün ve olguların dolaşımını, yeniden üretimini ve aktarımını sağlayan başlıca taşıyıcılardandır” (Ergil, 2020: 26). Bu çalışmada Dumas'nın bir özde çeviri ürünü olarak ele aldığımız Ali Pacha başlıklı özgün metninde yer alan yabancı bir bağlama ait yazınsal ve kültürel ürünlerle olguların, dolaşıma girmeden evvel öncelikle yazarın zihninde gerçekleşen bir çeviri işleminden geçip bunun sonucunda yeniden üretilerek yazarın öz bağlamına kendi diliyle taşınmış olduğu düşünülmüsstür. Böylece öncelikle yazarın zihninde işlenip Fransızcaya dönüşen kaynak metin, bu kez Fransızcadan İngilizceye, yani yine öz bağlam dilinden farklı bir dile taşınmış ve bu aktarım çalışmamızda dolaylı özde çeviri kavramı kapsamında incelenmiştir. Son olarak kaynak metin, Fransızcadan tarafımızca yapılan çeviriyle öz bağlam dili olan Türkçeye döndürülmüss ve bu aktarım da bu çalışmamızda aslına çeviri kavramı kapsamında ele alınmıştır.

Tepedelenli Ali Paşa'nın hikâyesi, 18. yüzyılda Osmanlı topraklarında başlayıp, 19. yüzyılda yine Osmanlı topraklarında son bulmaktadır; ancak hikâyenin geçtiği uzam artık Arnavutluk ve Yunanistan sınırları içindedir. Bu durumda öncelikle yer adları değişime uğramış bulunmaktadır. Kişilerin tümü gerçek olduğundan, Dumas'nın verdiği adların gerçeği yansıtıp yansıtmadığı da son derece önemlidir. Dumas, bu özel adları ve kimi kültürel öğeleri, kendi dilinde duyulduğu şekilde ve kendi araştırması ile algısı doğrultusunda yansıtmış ve yer yer de betimleme yoluna gitmiştir. Metnin İngilizceye yapılan dolaylı özde çevirisinde, bu tür göstergeler bağlamında Fransızca çıkış metni temel alınmış ve iki dilin benzerliklerinden de yararlanılarak genel anlamda paralel bir aktarım sağlanmıştır. Diğer yandan, Fransızcadan Türkçeye doğru aslına çeviri söz konusu olduğunda tam da aynı göstergelerin irdelenmesi ve araştırmanın derinleşmesi gerekmiştir. Örneğin, Dumas'nın tarif etme yoluyla tanımlamaya çalıştığı her olgunun ve hatta nesnenin ne olduğunu saptama zorunluluğu söz konusu olmuştur. Öte yandan, kaynak metinde kullanılan bazı ifade ve hitapların hikâyenin geçtiği zaman, uzam ve bağlam doğrultusunda düşünülmesi gerekmiştir. Bunun yanı sıra, özde çeviri metninde yer alan kimi hatalı bilgilerin saptanarak aslına çeviri metnine dip not düşülmek suretiyle düzeltilmesi de söz konusu olmuştur. İngilizceye yapılan dolaylı özde çevirinin ise çevirmene bu türden özdeş yükümlülükler yüklememiş olabileceği, ancak buna karşıllk çevirmenin kimi yerel ve kültürel metinlerarası öğelerin çözümlenmesi noktasında özel bir uğraşı vermiş olabileceği söylenebilir. Bu noktada, aslına çevirinin de kimi tanıdık göstergelerin aktarımı noktasında metni öz bağlamına döndüren çevirmen açısından kolaylıklar sunduğunu da ifade etmek gerekir. Öte yandan, kadına şiddete yönelik göstergelerin istisnasız olarak her dilde karşılığının bulunduğunu da eklemekte fayda vardır.

Sonuç olarak, kolay ve zorlu yönleriyle "[...] çevirmen her bir çeviri etkinliğ̈inde yeni ve o çeviri sürecine özgü bir eyleyicilik görevi üstlenir” (Ergil, 2020: 28). Bu durum, bütüncemizi oluşturan özde 
çeviri, dolaylı özde çeviri ve aslına çeviri (Öztürk Kasar, 2012; 2020) ürünleri bağlamında da geçerliliğini korumuştur; zira metinleri ortaya koyma noktasında yazar ve çevirmenlerin her bir ürüne özgü farklı deneyimlerden geçtikleri ve metinlerini farklı gereksinimler doğrultusunda farklı çözüm arayışlarına yönelerek oluşturdukları açıktır. Bu süreçlerde gerek özde çeviriyi gerekse dolaylı özde çeviri ve aslına çeviriyi yer yer "zor bir iddia olarak, kimi zaman da kazanılması olanaksız bir iddia olarak” (Ricœur, 2008: 9) tanımlamak yanlış olmayacaktır; zira farklı açılardan da olsa, her bir durum özelinde kimi "çevrilmezlik alanları metnin içine serpiştirilmiştî" (Ricœur, 2008: 10). Son olarak, karma nitelikli bir metin söz konusu olduğunda, yüz sayfalık bir kitabın çevirisi için bin sayfalık araştırma yapmak, ya da bir kitap çevirmek için on kitap okumak gerekebilmektedir. Diğer yandan, yine karma nitelikli bir metin söz konusu olduğunda, her bir sayfada karşısına çlkabilecek çok çeşitli metinlerarası unsurdan dolayı, çevirmenin neyi çevirip neyi çevirmeyeceği üzerinde kesin ve net bir kontrolü olduğundan söz etmek çok mümkün olmamaktadır.

\section{Kaynakça}

Aktulum, K. (2007). Metinlerarası ilişkiler. İstanbul: Öteki.

Alexandre Dumas. Deux siècles de littérature vivante. www.dumaspere.com/pages/dictionnaire/crimes_celebres.html [01.08.2020]

Bakhtin, M. (2001) Karnavaldan romana. Edebiyat teorisinden dil felsefesine seçme yazılar. İstanbul: Ayrıntı.

Boztaş, İ., Okyayuz Yener, Ş. (2005). Açıklamalı çeviri terimleri sözlüğü. 2. bs. Ankara: Siyasal Kitabevi.

Dumas, A. (1840). Ali-Pacha, L'homme au masque de fer, Les crimes célèbres. Vol. 7-8. Bibliothèque numérique romande. www.ebooks-bnr.com

Dumas, A. (2004). Ali Pacha, Celebrated crimes, Complete. https://www.gutenberg.org/ files/ 2760/276o-h/276o-h.htm.

Dumas, A. (2020). Tepedelenli Ali Paşa (D. Tuna, Çev.). İstanbul: Kırmızı Kedi.

Ergil, B. (2020). Batı kanonu hayal perdesinde: Tiyatrotem yeniden yazım ve yeniden çevirilerinde "absürd", "tragedya" ve "komedya" kavramlarının dönüşümü. Dünya Dilleri, Edebiyatlar ve Çeviri Çalışmaları Dergisi, 1(1), 26-58.

Irzık, S. (2001) Önsöz. Karnavaldan romana. Edebiyat teorisinden dil felsefesine seçme Yazılar (M.Bakhtin). İstanbul: Ayrıntı.

Kristeva, J. (1980). Desire in language: A semiotic approach to literature and art. New York: Columbia University Press.

Kristeva, J. (1986). Word, dialogue and novel. Tril Moi (Ed.). The Kristeva Reader içinde (s. 34-61). New York: Columbia University Press.

Nato review. Çatışmalarla bağlantılı cinsel şiddet. https://www.nato.int/docu/review/tr/articles/ 2017/10/26/ catismalarla-baglantili-cinsel-siddet/index.html.

Öztürk Kasar, S. (2009). Pour une sémiotique de la traduction. La traduction et ses métiers. In Colette Laplace, Marianne Lederer, Daniel Gile (Eds). Caen: Lettres Modernes Minard, 2009: 163-175.

Öztürk Kasar, S. (2012). Traduction de la ville sous le point de vue sémiotique : Istanbul à travers ses signes en trois langues. In N. Rentel \& S. Schwerter (Dir.). Défis et enjeux de la mediation interculturelle (pp. 267-285). Frankfurt am Main: Peter Lang.

Öztürk Kasar, S. (2020). Çeviri göstergebilimi ile kent göstergebiliminin bütünleşik bağlamında özde çeviri kavramının incelenmesi. Dünya Dilleri, Edebiyatları ve Çeviri Çalışmaları Dergisi, 1(1), 1-25.

Reverso Dictionnaire. https://dictionnaire.reverso.net

Ricœur, P. (2008). Çeviri Üzerine. (Öztürk Kasar, S., Çev.). İstanbul: YKY. 
904 / RumeliDE Journal of Language and Literature Studies 2020.S8 (November)

An act of translation in the author's mind: The source text as a product of watermark translation and its retro-translation / D. Tuna (pp. 882-904)

Türk Dil Kurumu Güncel Türkçe Sözlük. https://tdk.gov.tr

Türkiye Diyanet Vakfi İslam Ansiklopedisi. https://islamansiklopedisi.org.tr 